\title{
Final evaluation results: Expanding access to secondary school education for teenage mothers in Homa Bay County
}

\author{
Chi-Chi Undie \\ Population Council \\ Harriet Birungi \\ Population Council \\ George Odwe \\ Population Council \\ Francis Obare \\ Population Council
}

Follow this and additional works at: https://knowledgecommons.popcouncil.org/departments_sbsr-rh How does access to this work benefit you? Let us know!

\section{Recommended Citation}

Undie, Chi-Chi, Harriet Birungi, George Odwe, and Francis Obare. 2020. "Final evaluation results: Expanding access to secondary school education for teenage mothers in Homa Bay County," presentation. Nairobi: Population Council. 


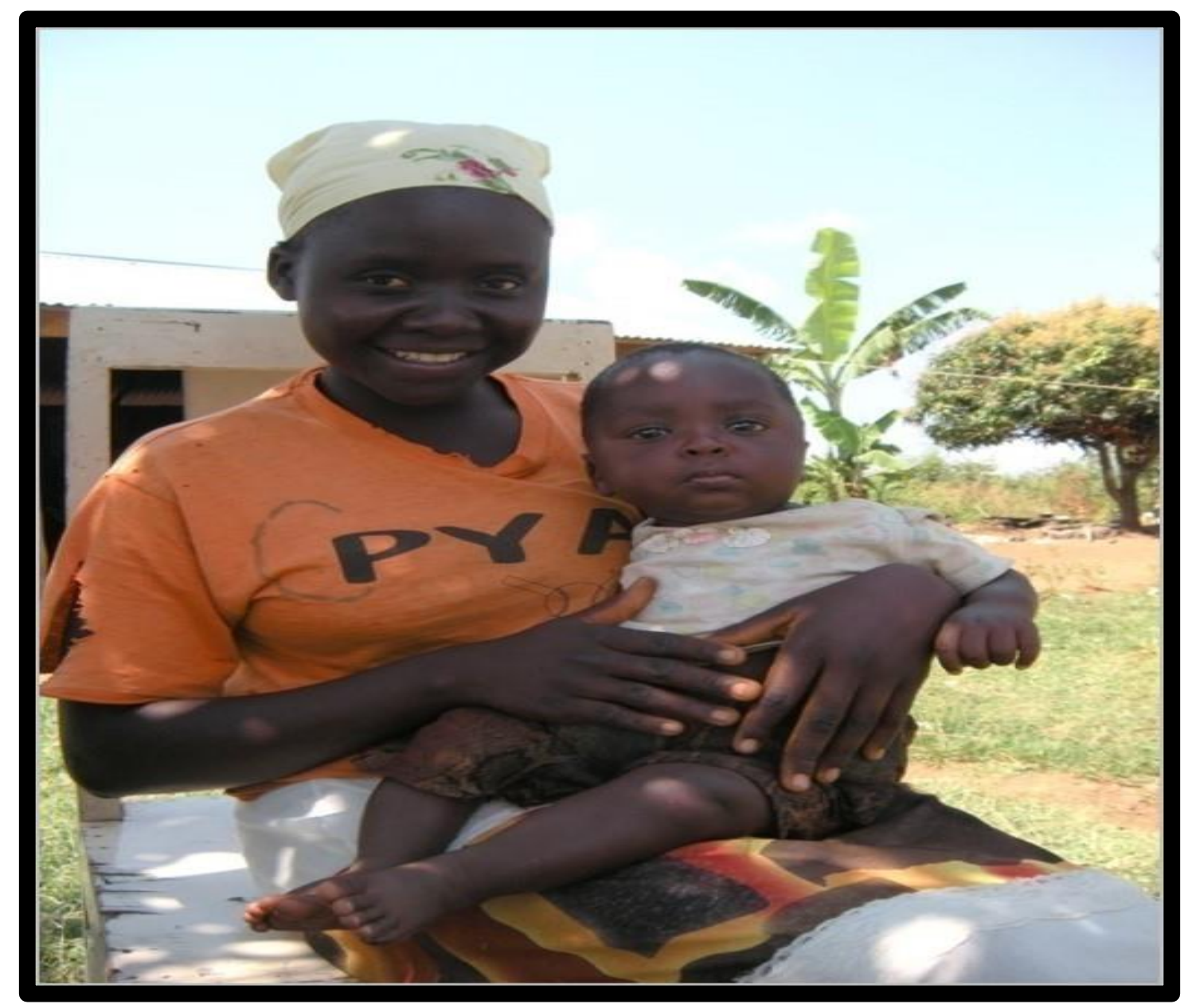

\section{Final Evaluation Results}

Expanding Access to Secondary School Education for Teenage Mothers in Homa Bay County 


\section{Study Objective}

- To determine the effect of policy dialogue, clarification, and advocacy on:

- the demand for secondary school education by out-of-school teenage mothers; and

- community knowledge, attitudes, and practices in regard to school re-entry for out-of-school teenage mothers. 


\section{Study Sites}

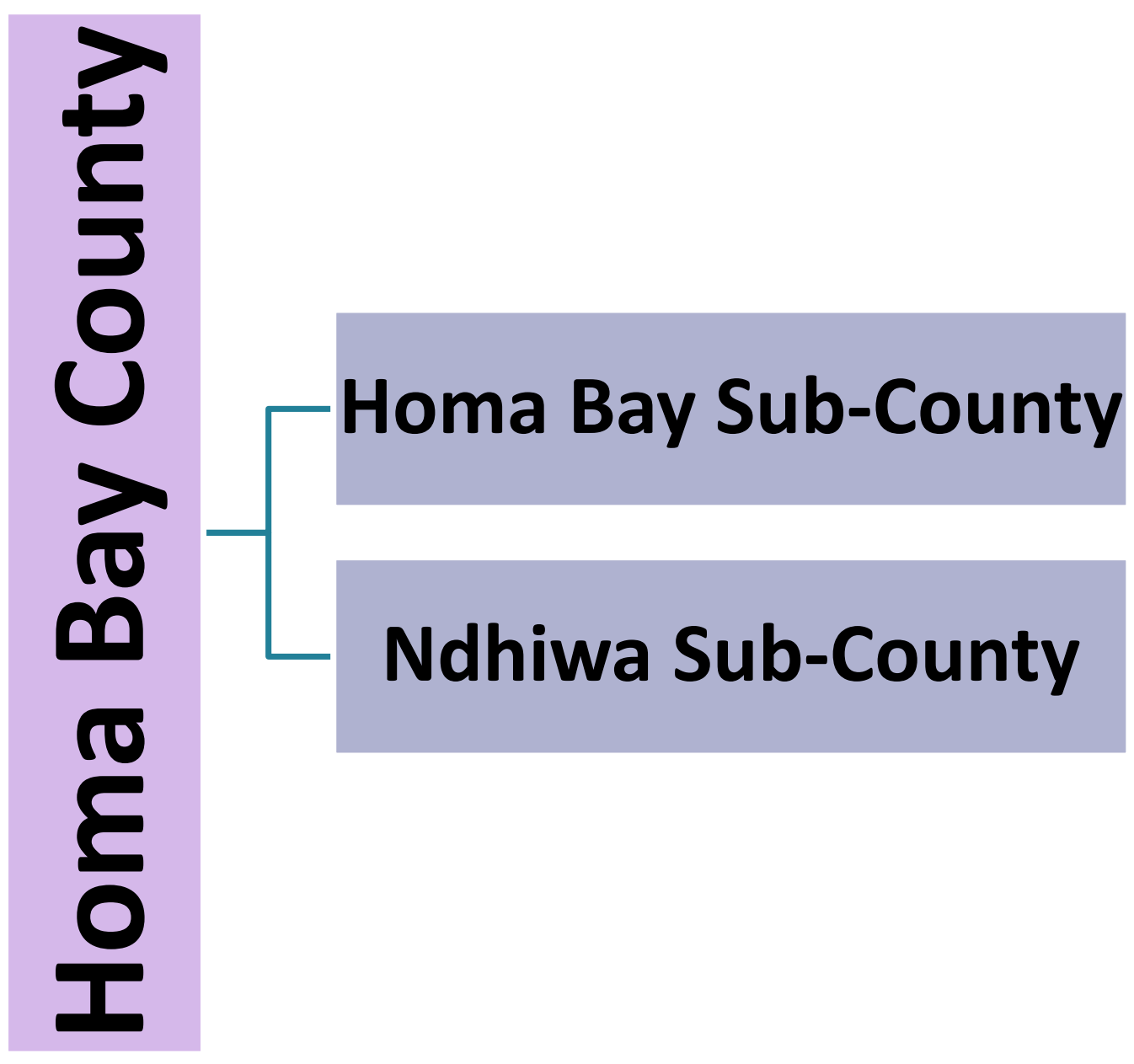




\section{Study Populations}

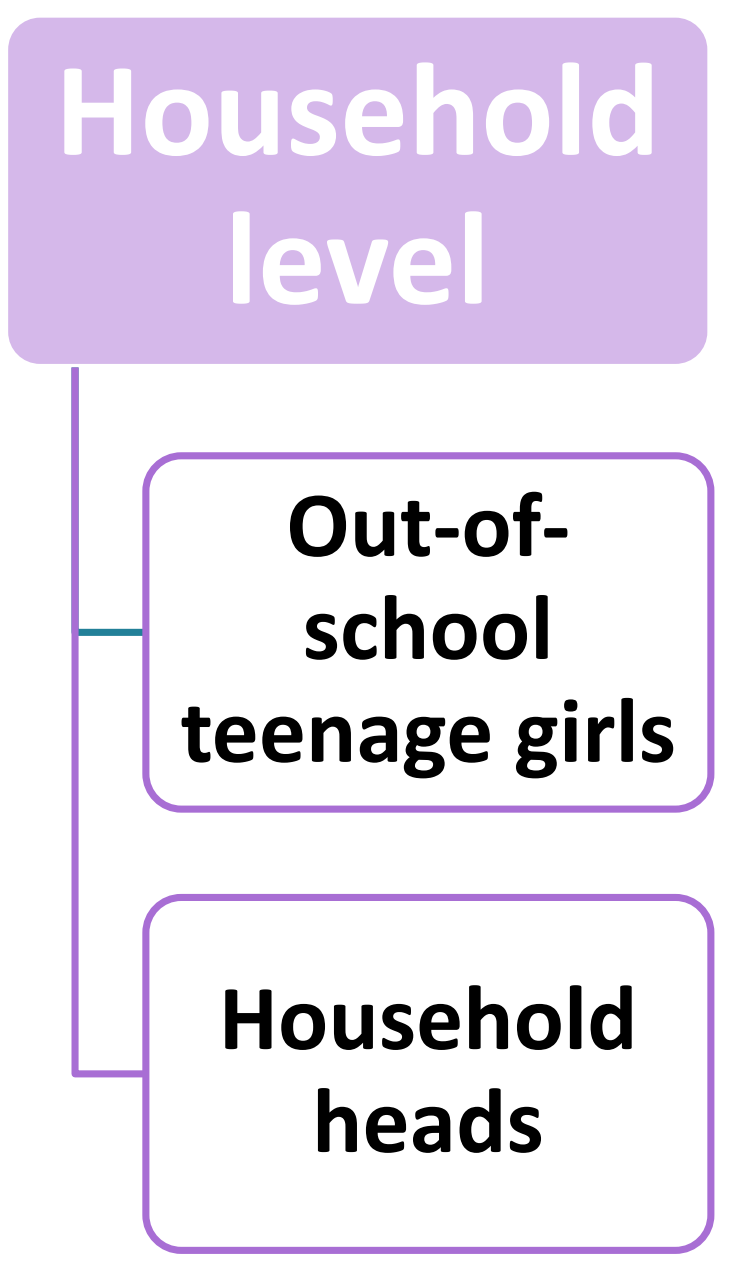

\section{School level}

Secondary school principals

Secondary school students 


\section{Study Design}

- Pretest-Postest Design

Time

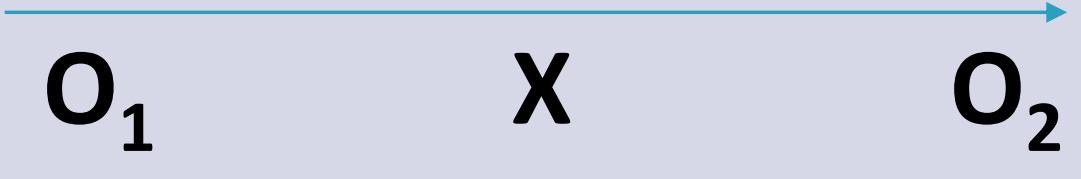




\section{Data Gathering Activities}

- Baseline and endline household surveys

- Out-of-school teenage girls; HHHs

- Baseline and endline, self-administered school surveys

- Secondary school principals and students

- School re-entry statistics

- All (eligible) primary and secondary schools in Homa Bay sub-county 


\section{Sample Sizes}

Out-of-school teenage girls, ages 13-19

$$
(n=727)
$$

Household heads of out-of-school teenage girls

$$
(n=511)
$$

Secondary school principals:

public, day, mixed or girls-only

30 randomly sampled from each sub-county

$(n=167)$

Secondary school students

Forms 2 and 3

$(n=1,413)$ 


\section{Key Findings at Baseline (September-October 2014)}

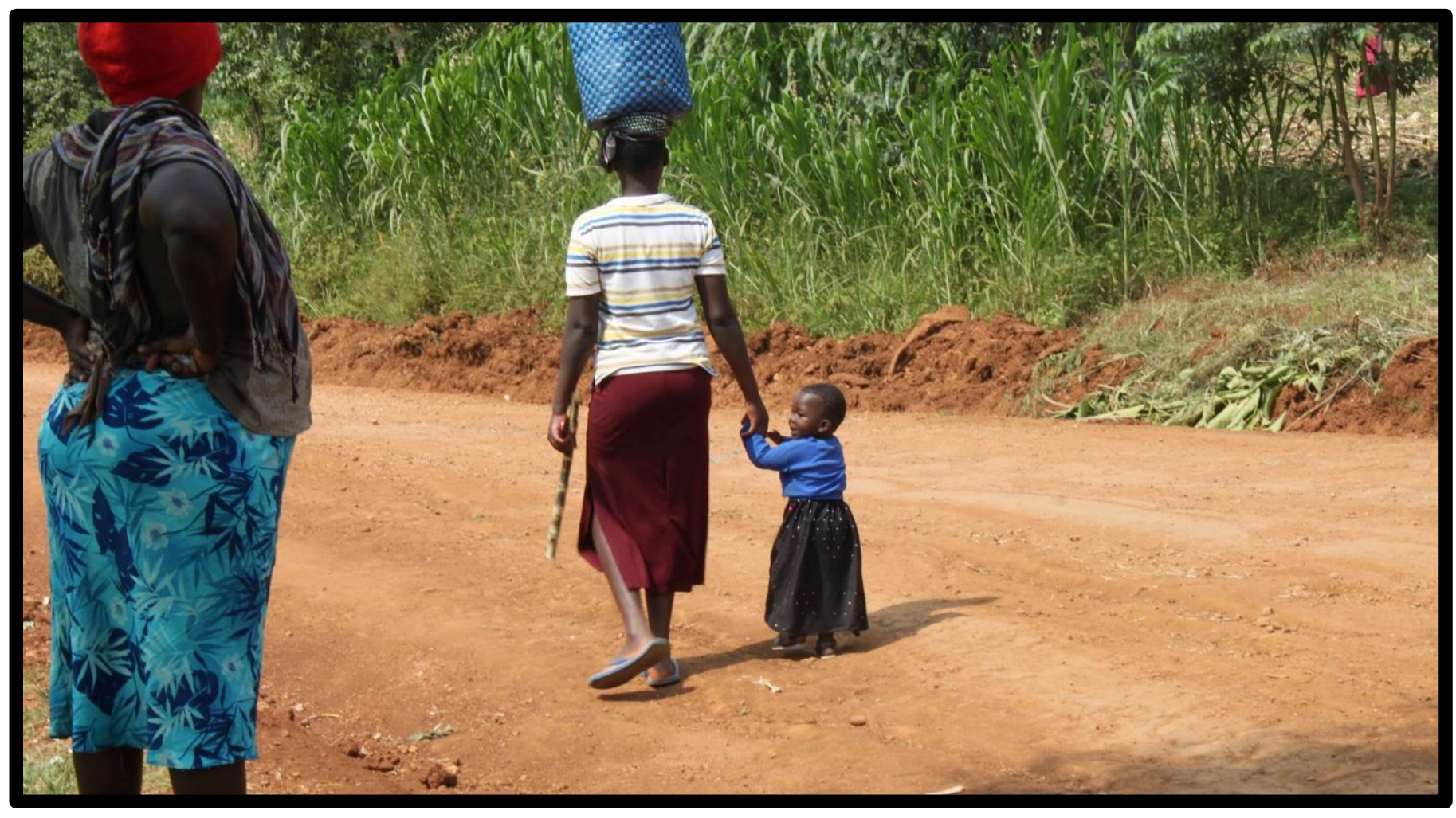




\section{Pregnancy is a pivotal event in the lives of girls in Homa Bay}

- It often precedes or

leads to school dropout

$-66 \%$ of out-ofschool teen girls cited pregnancy as their main reason for leaving school

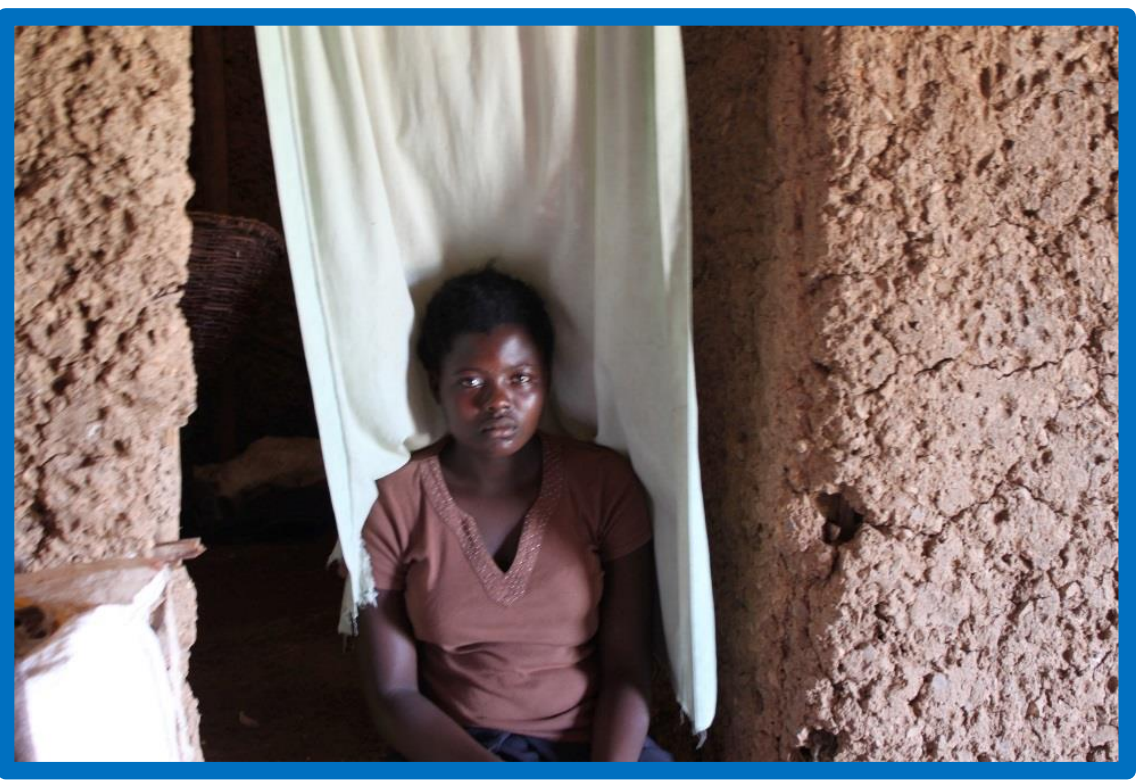




\section{Pregnancy is a pivotal event in the lives of girls in Homa Bay}

- It occurs early

$-80 \%$ of out-ofschool girls who cited pregnancy as their main reason for leaving school, left school at the primary school level

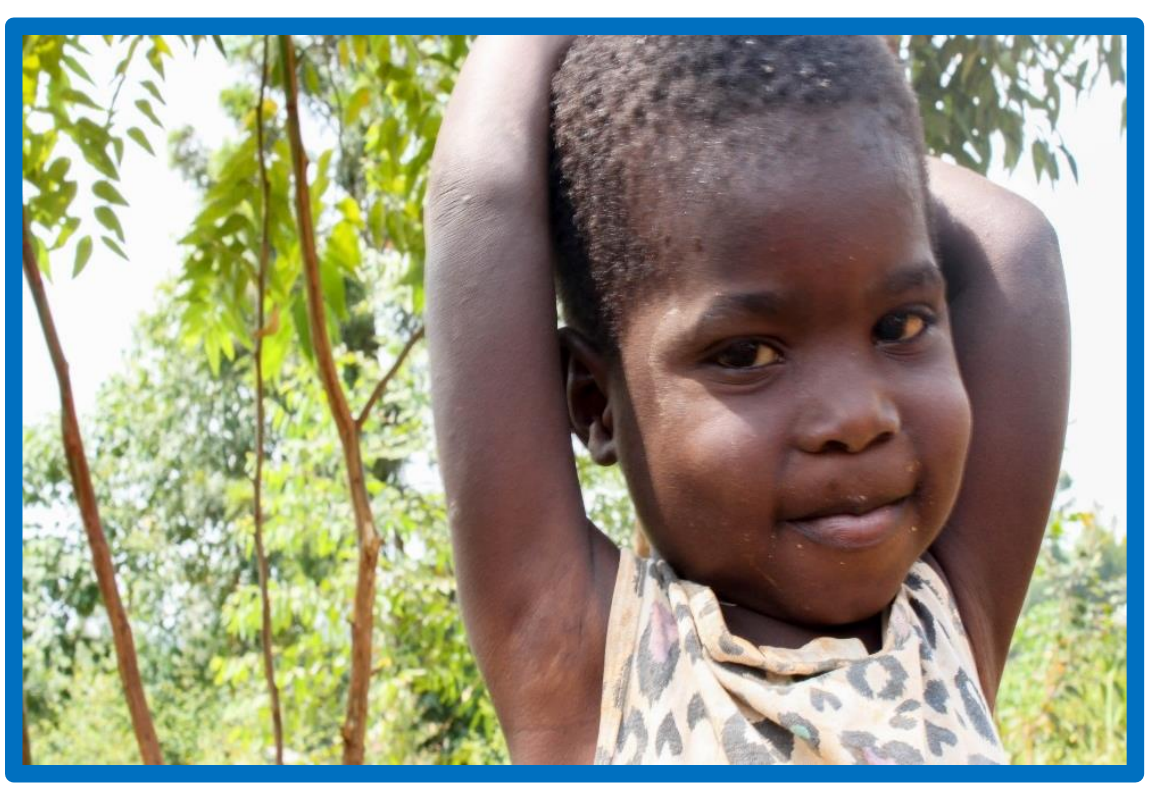




\section{Pregnancy is a pivotal event in the lives of girls in Homa Bay}

- It often leads to

early marriage

- A third of out-ofschool girls were married. Of these, 92\% said they got married because they got pregnant.

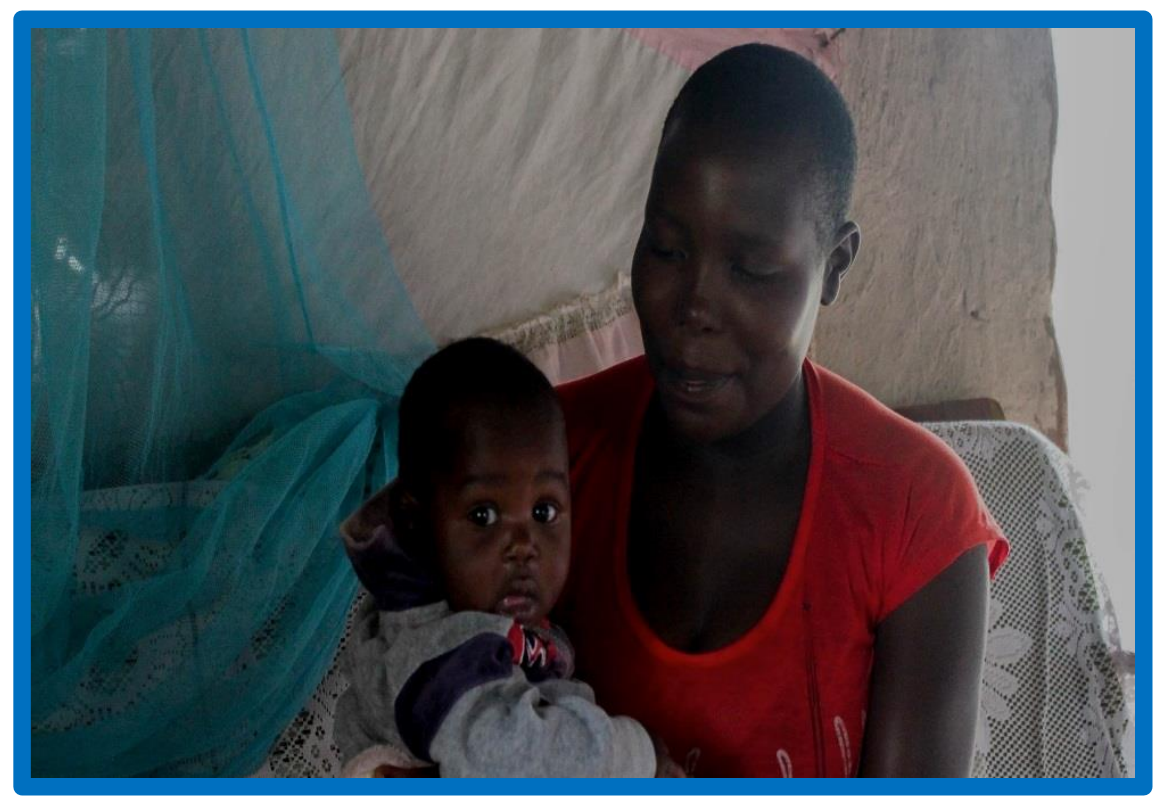


Pregnancy: A pivotal event in the lives

$$
\begin{gathered}
\text { of girls in Homa Bay } \\
\mathbf{9 1 \%}
\end{gathered}
$$

of out-of-school girls would like to go back to school someday

\section{$76 \%$}

intend to go back to school someday

Finances and child care are the main barriers, according to girls and $\mathrm{HHHs}$ 
School contexts are important for understanding teenage pregnancy in Homa Bay

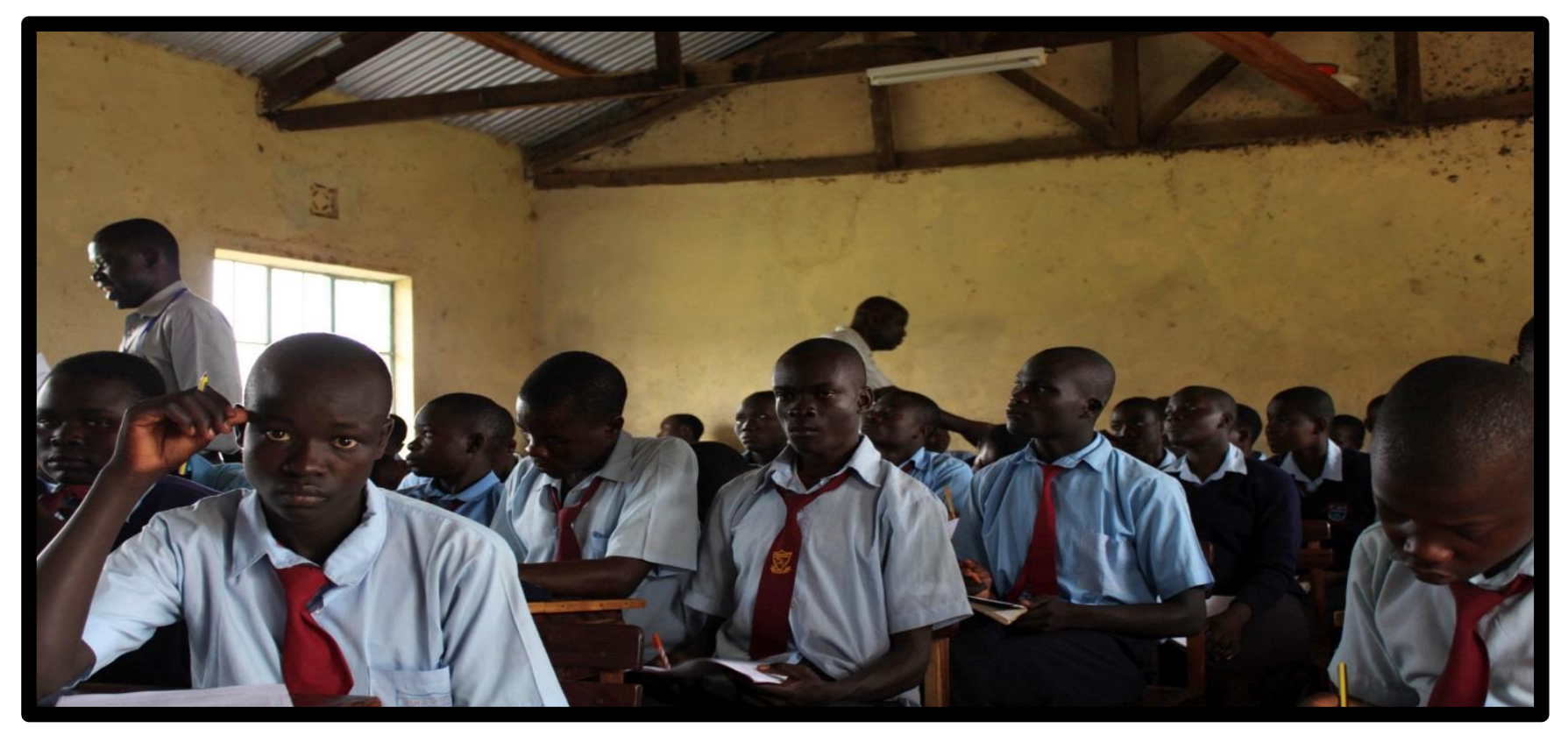

- School pregnancy rates are high:

- A quarter of school principals reported having 5 or more pregnant girls in their schools in the last year. 
School contexts are important for

understanding teenage pregnancy in

Homa Bay

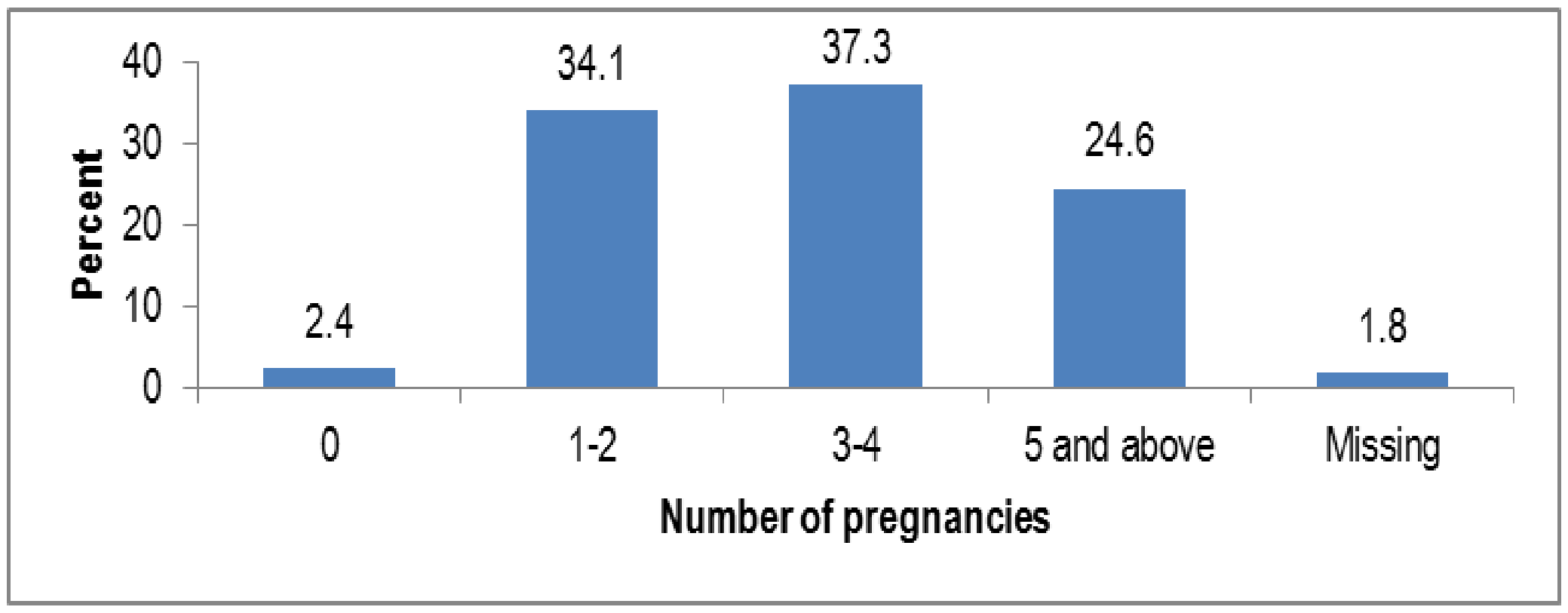

- School pregnancy rates in the last year (August 2013-August 2014) 


\section{Who got you pregnant?}

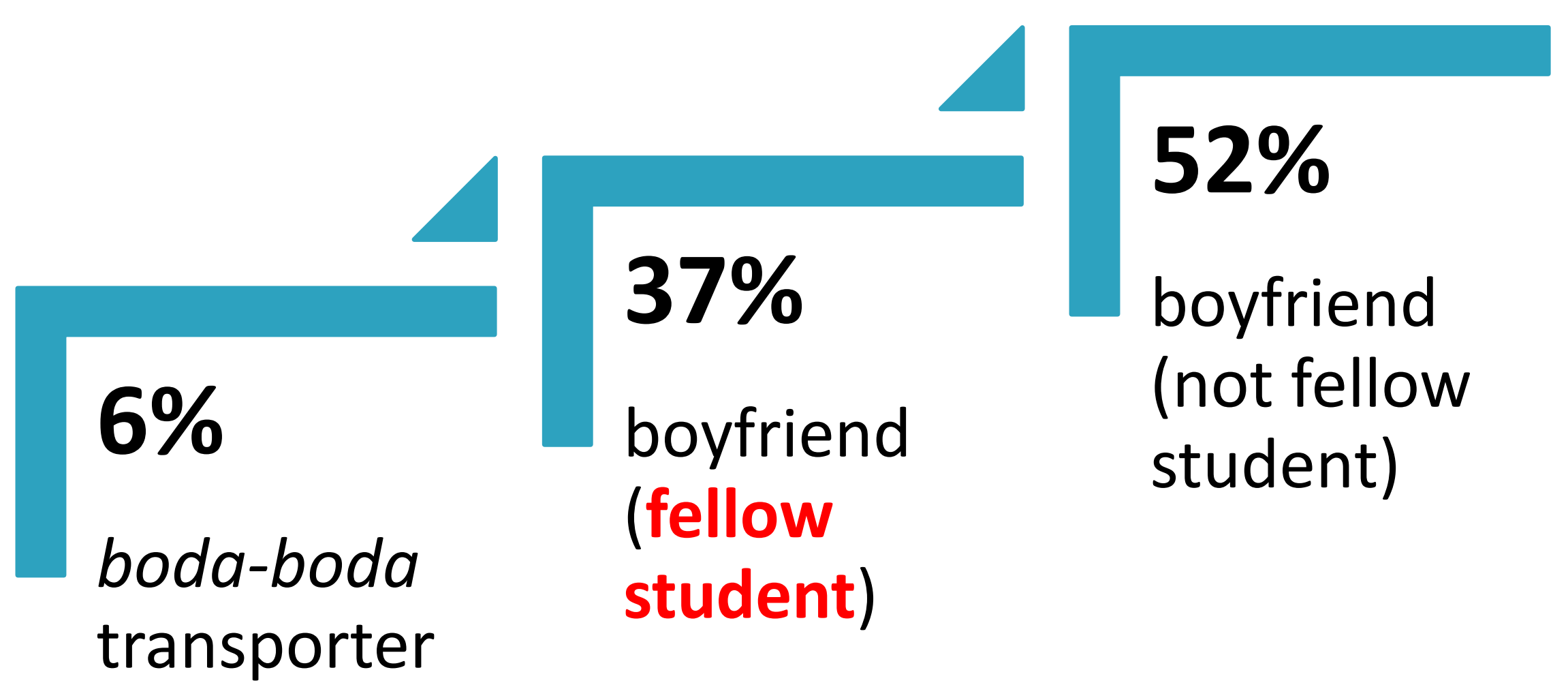




\section{School contexts are important for}

understanding teenage pregnancy in

Homa Bay

(secondary school students, $n=1,413$ )

Ever gotten

a girl

pregnant?
Ever gotten pregnant?

\section{YES}

\section{YES}

$19 \%$

\section{$21 \%$}


School contexts: Important for understanding teenage pregnancy in Homa Bay

'Schools need to help girls avoid pregnancy.'

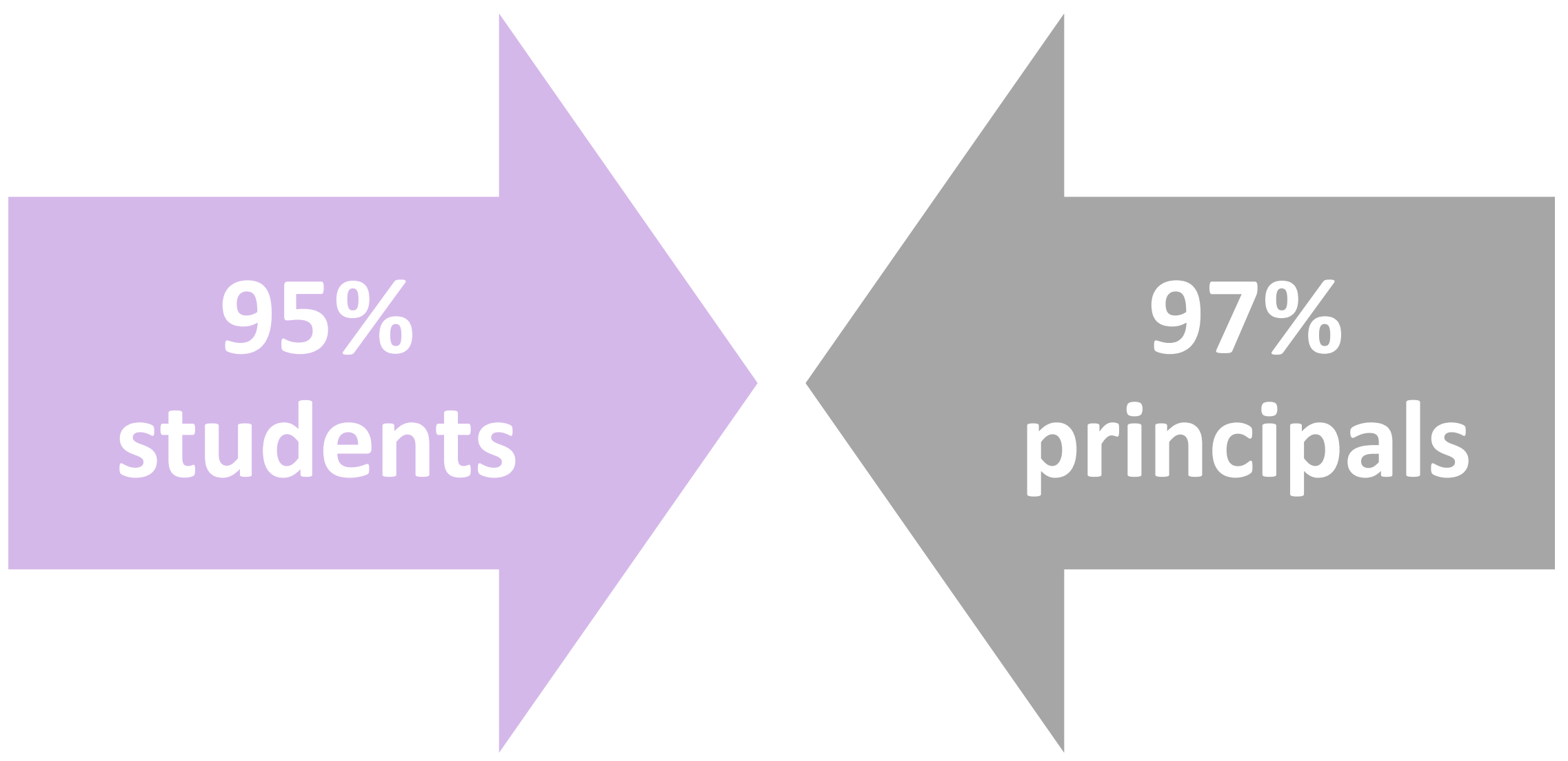




\section{School contexts: Important for}

understanding teenage pregnancy in Homa Bay

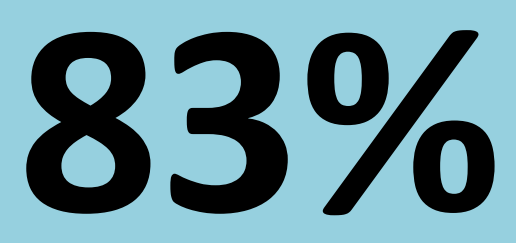

students say schools don't provide info on where to access contraception 
Policy awareness needs enhancement in Homa Bay

Not aware of the NSHP

\section{$36 \%$}

$$
\text { out-of- }
$$

school girls

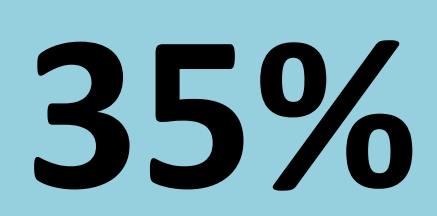

household heads 
Policy awareness needs enhancement in Homa Bay

Not aware of the NSHP

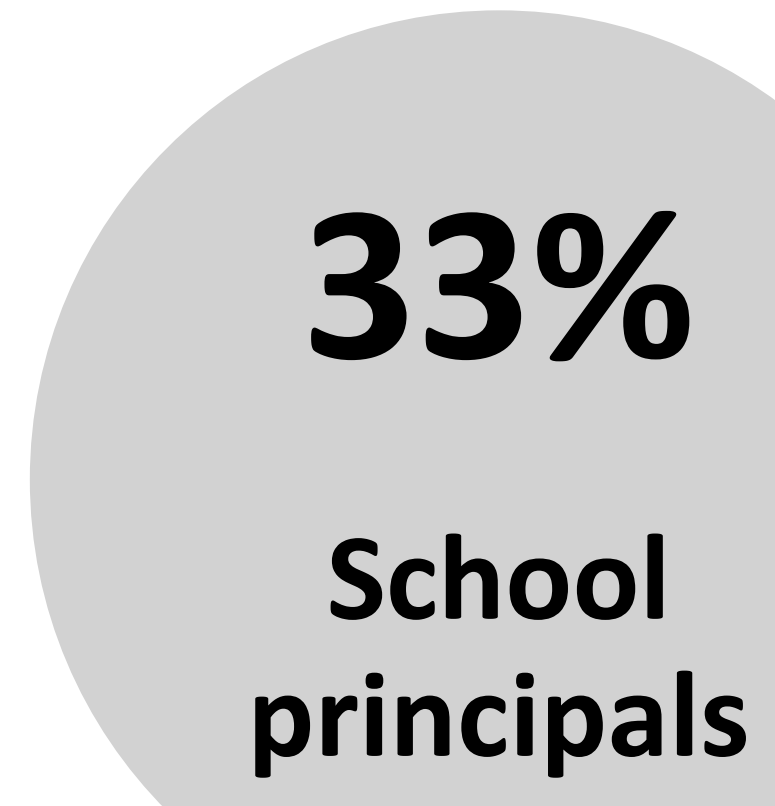

$44 \%$

Students 
Policy awareness needs enhancement in Homa Bay

Not aware of the school re-entry policy

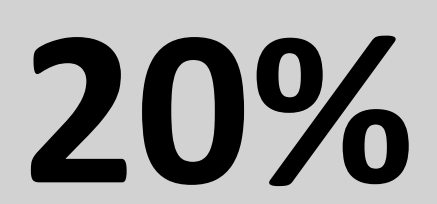

$16 \%$

School

principals

\section{Students}




\section{Radio is important for conveying policy information in Homa Bay}

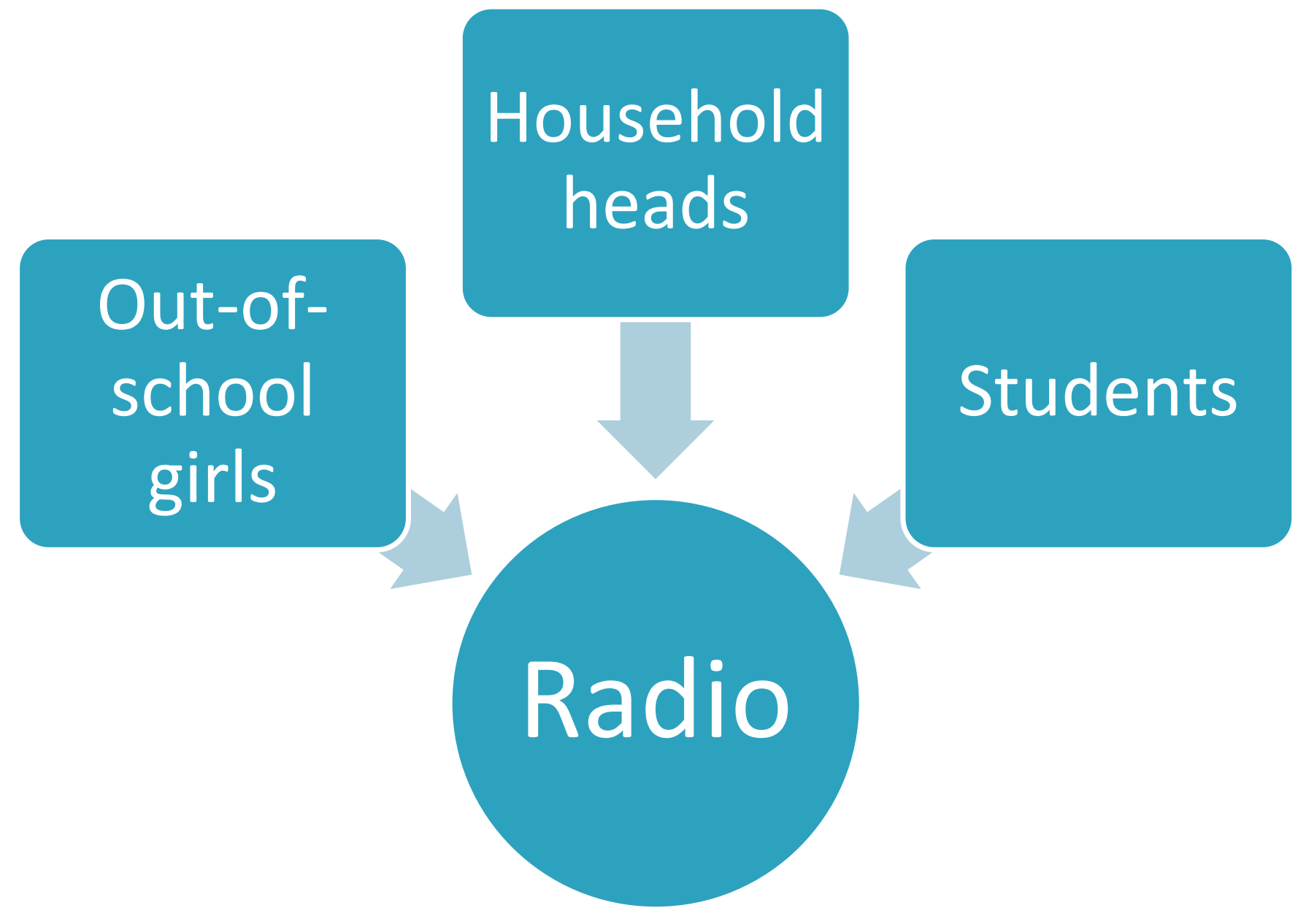




\section{Interventions}

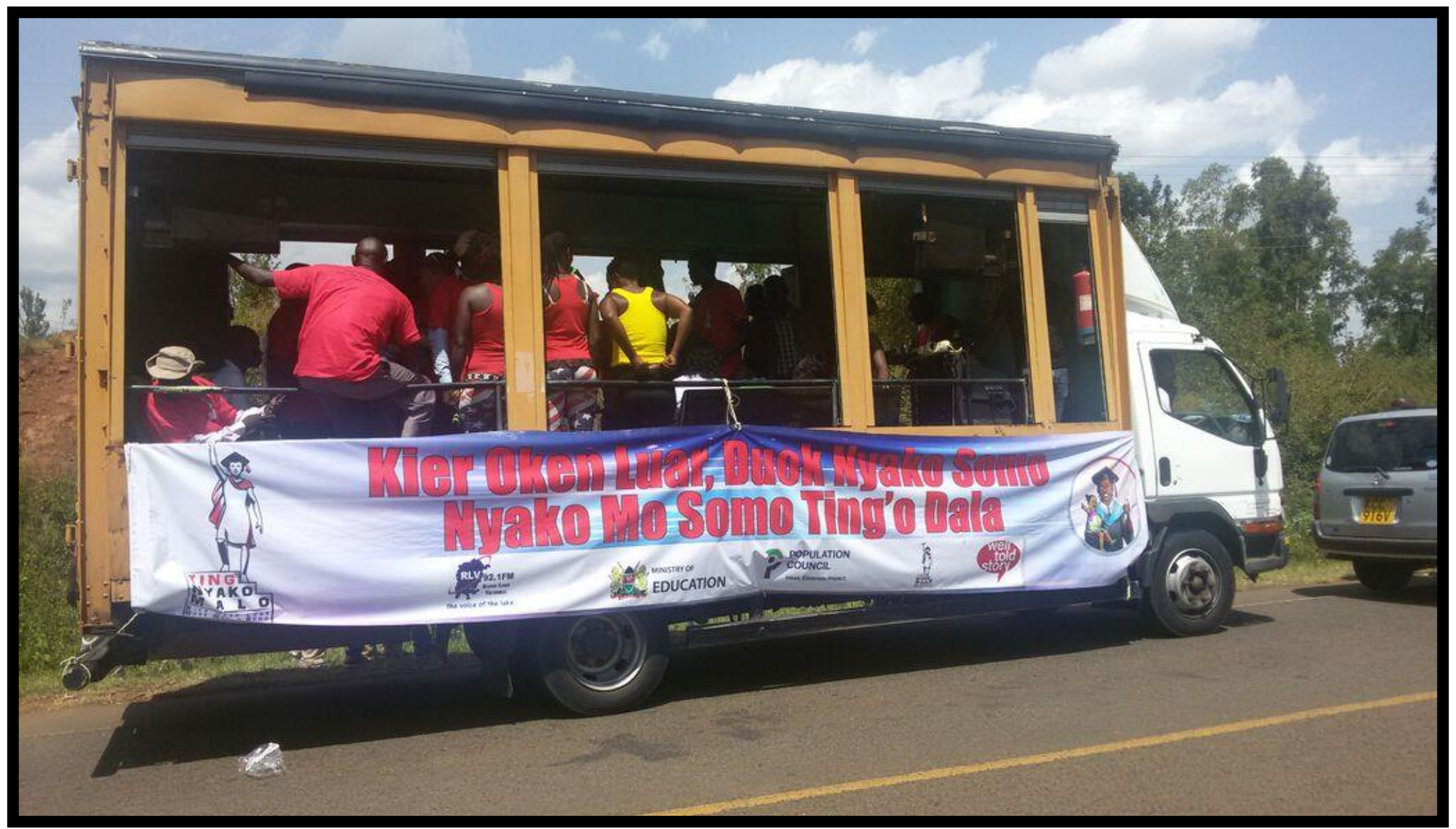




\section{Interactive media campaign}

- By Well Told Story for 18 weeks (July-Nov, 2015)

- 'Real-life' radio series

- Expert interviews (MOE, principals, community leaders, etc.) on policies

- Call-ins, prizes

- Complementary IEC materials on policies

- Road shows

- Engagement of local celebrity ('Odoshe'), MPs
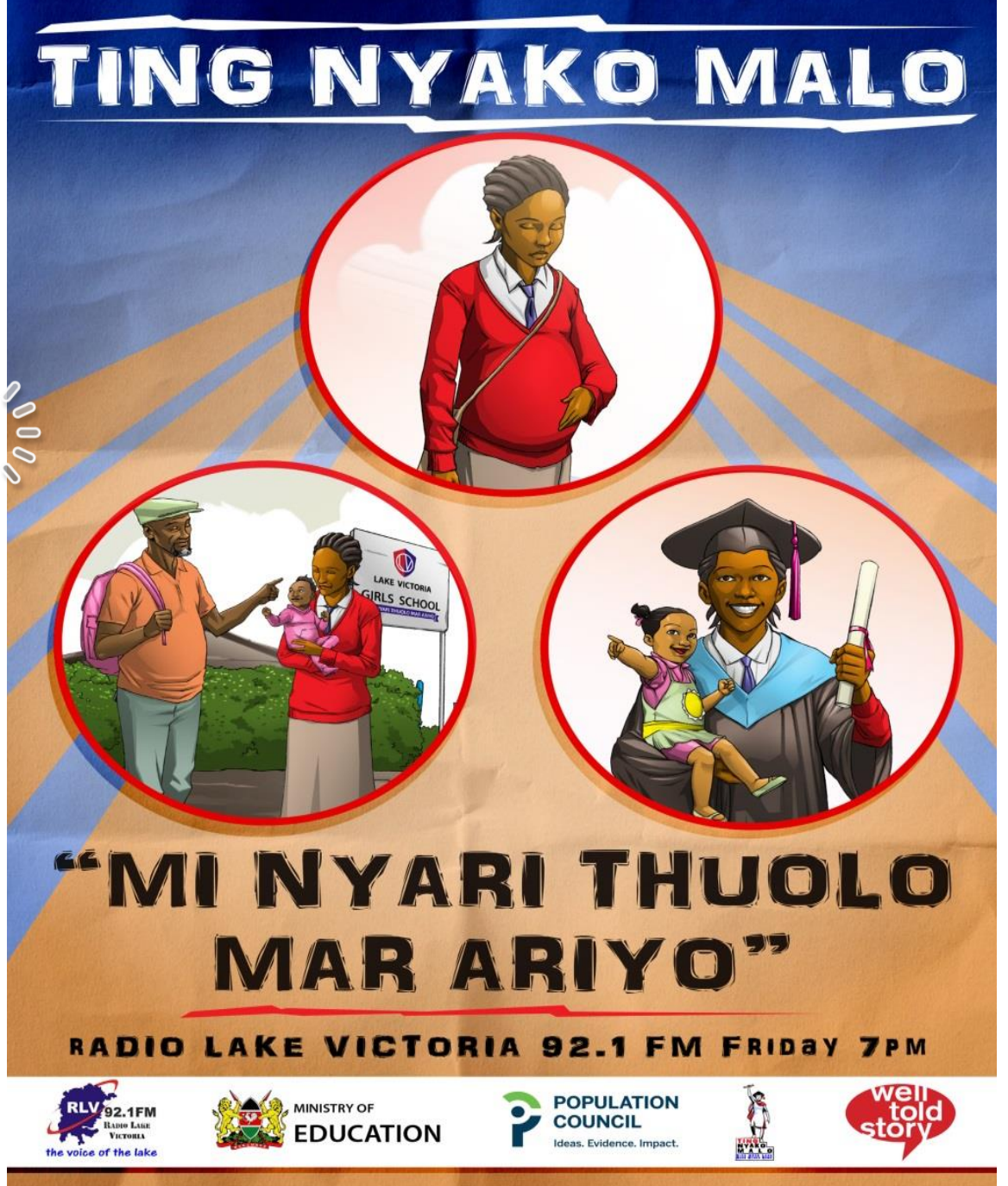


\section{Odosh Jasuba}

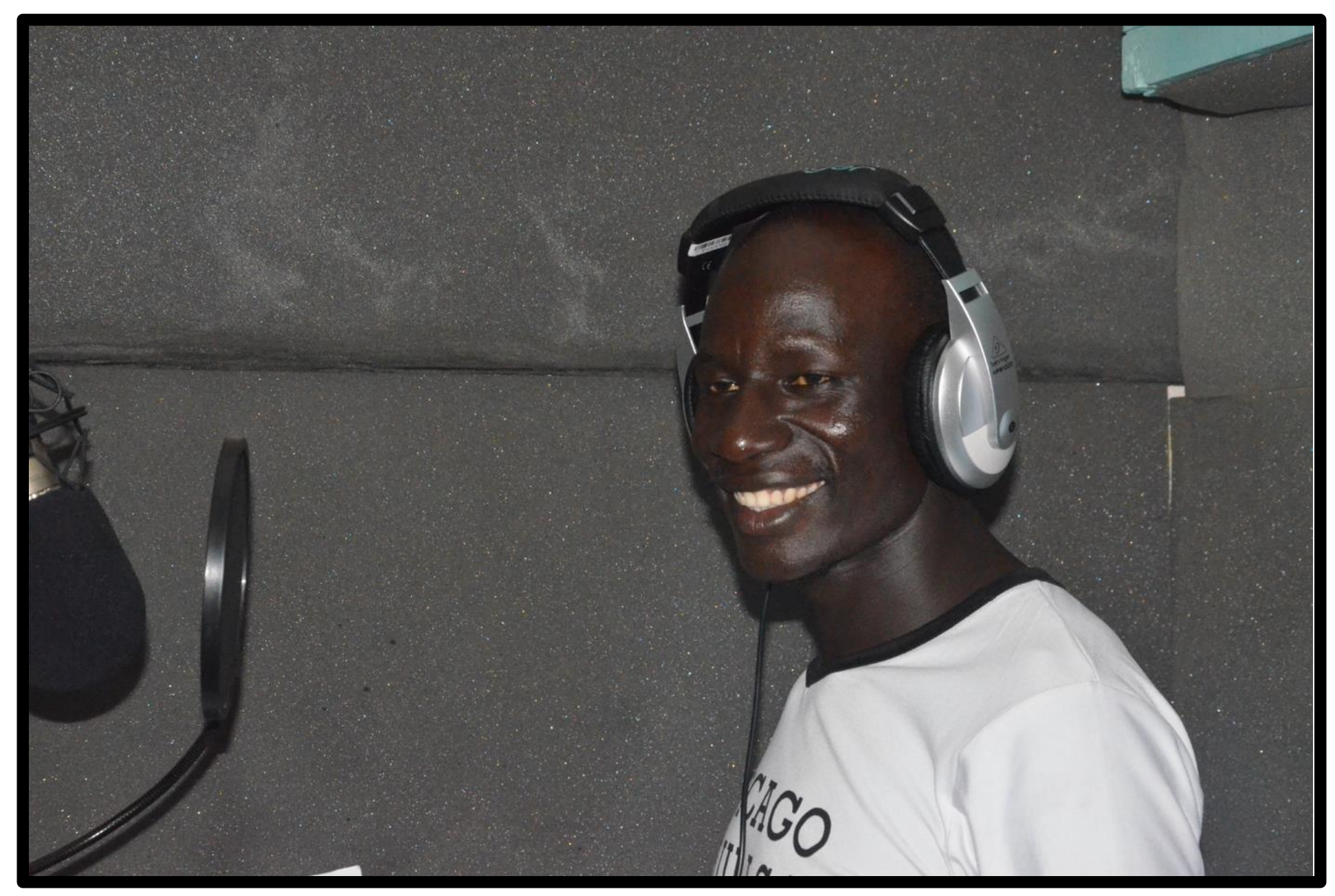




\section{Media campaign launch}
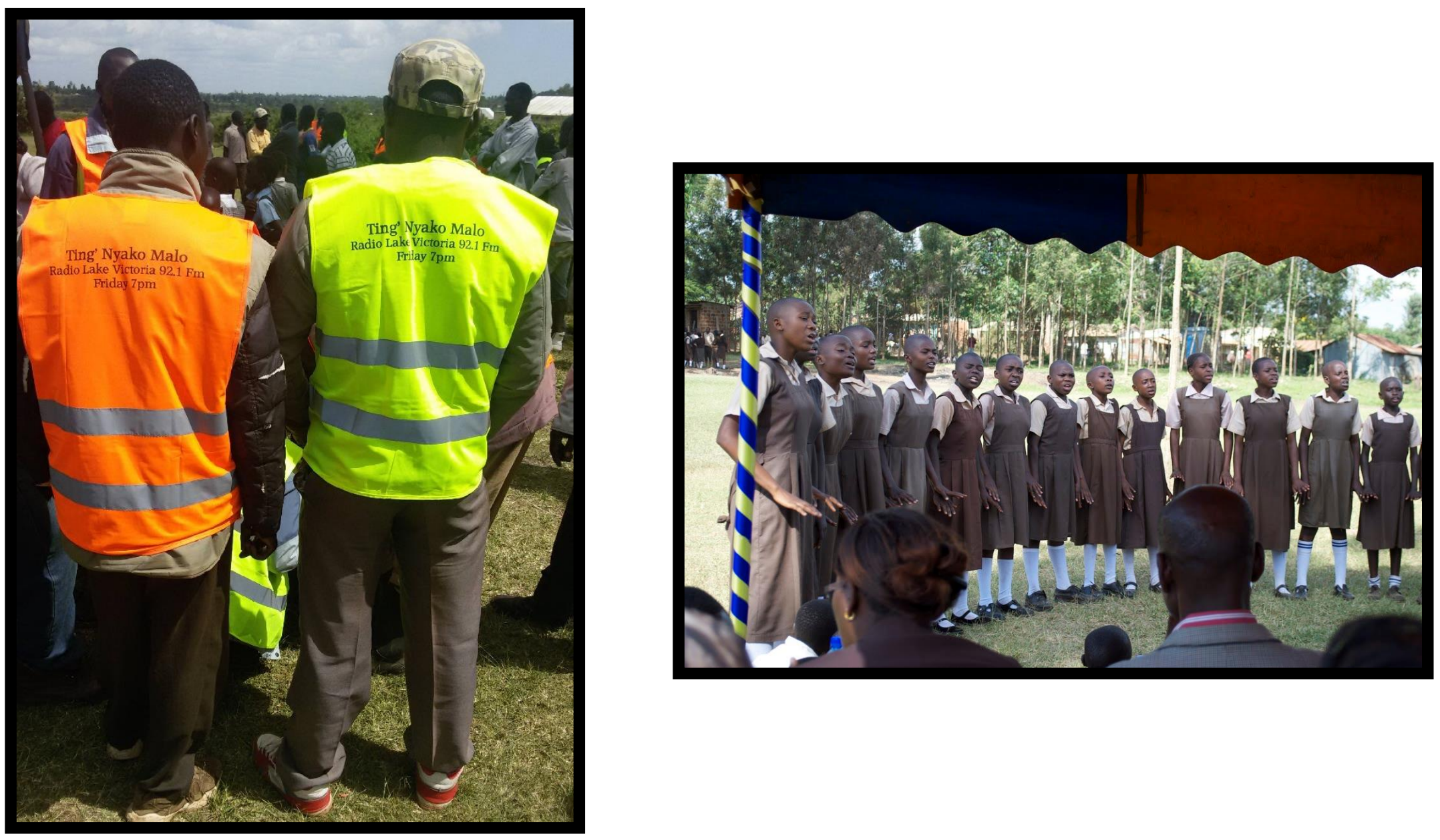


\section{Media campaign launch}

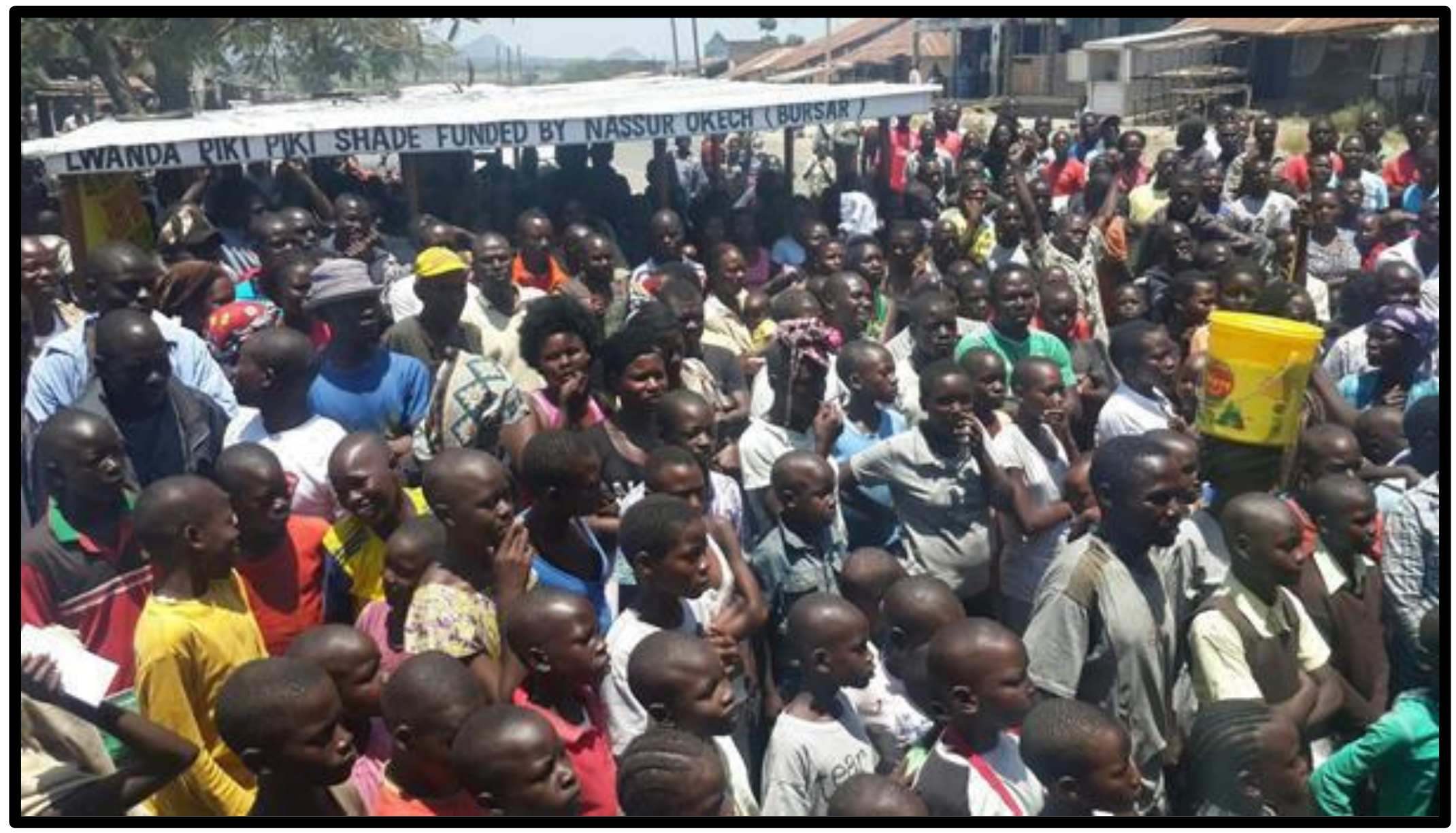



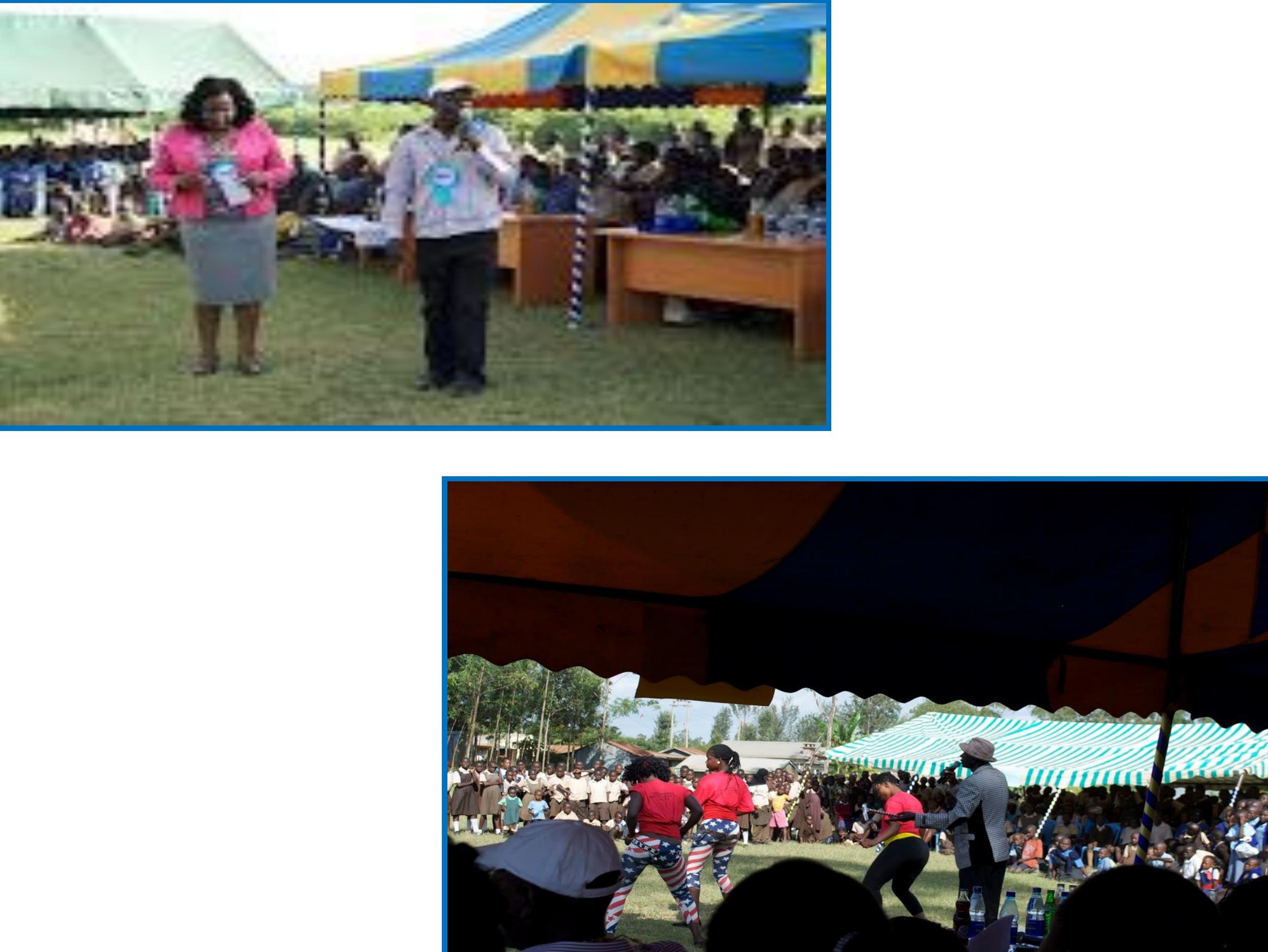


\section{Preliminary Key Findings at Endline (January to February 2016)}

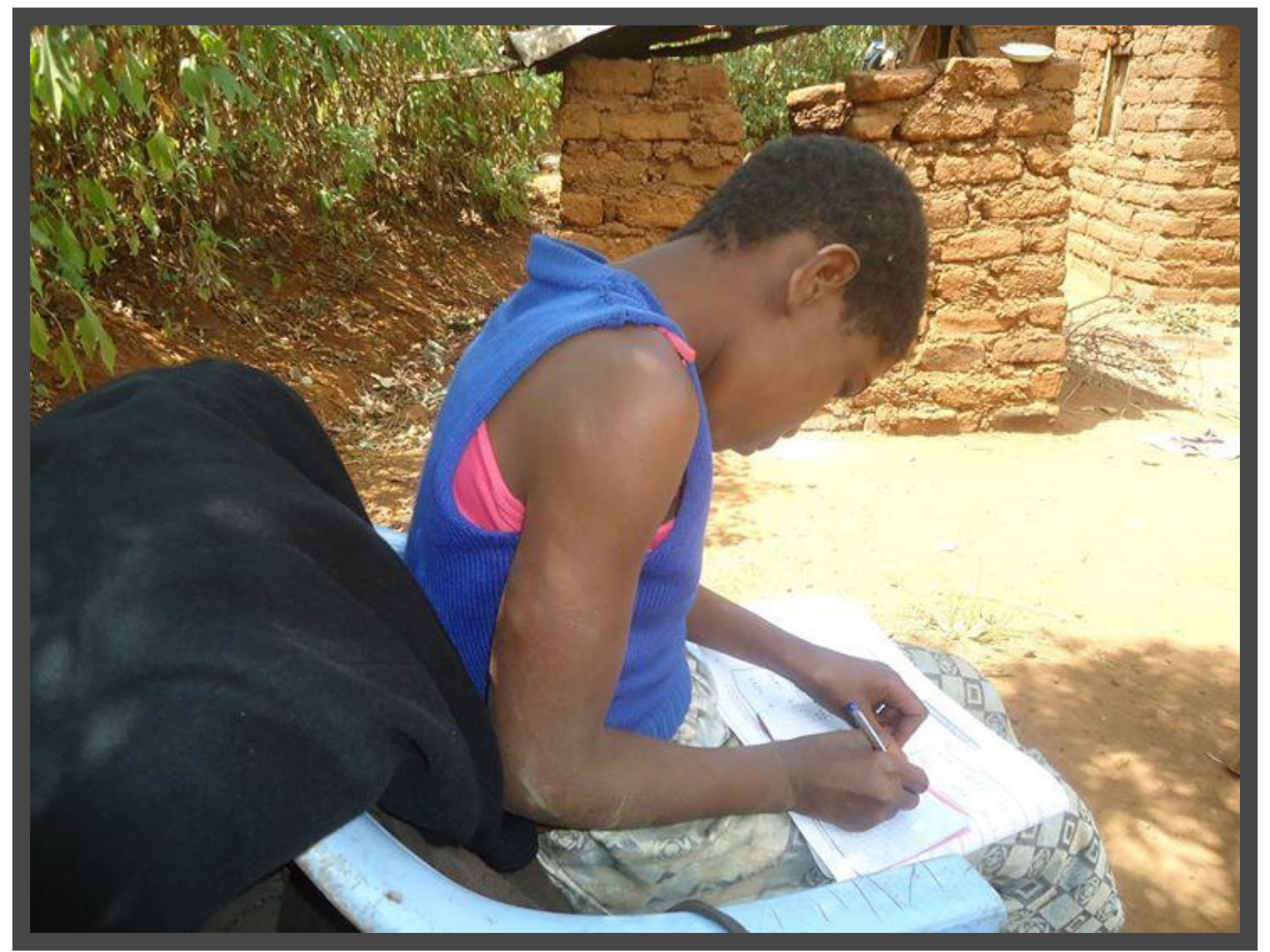

Photo by Uwezo Kenya 


\section{An increase in household togetherness}

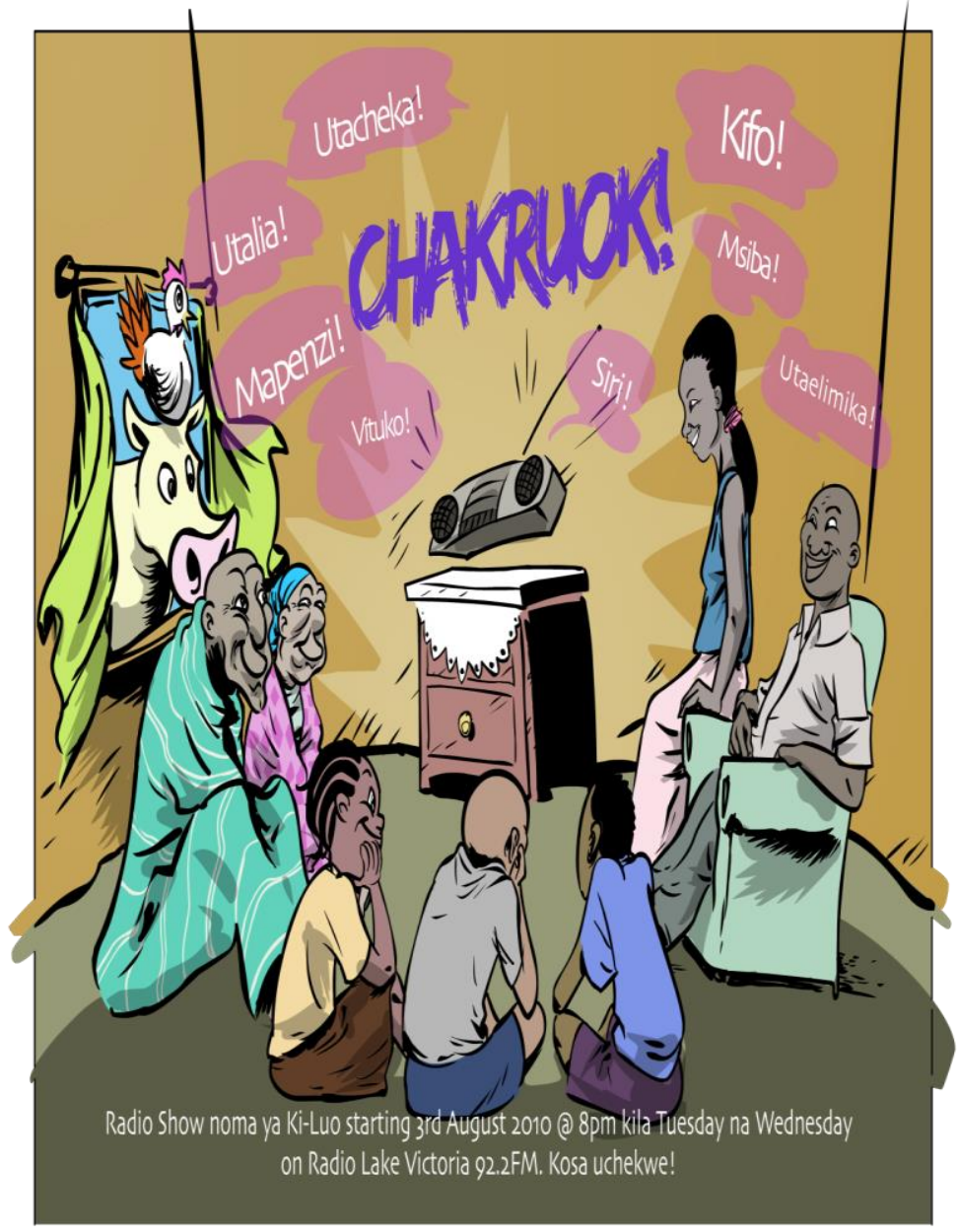

- Proportion of out-ofschool teenage girls reporting that they listen to radio with their $\mathrm{HHH}$ :

- Baseline: 74\%

- Endline: 92\%

- $p<0.001$ 


\section{An increase in policy awareness}

Ever heard radio messages about need for school re-entry

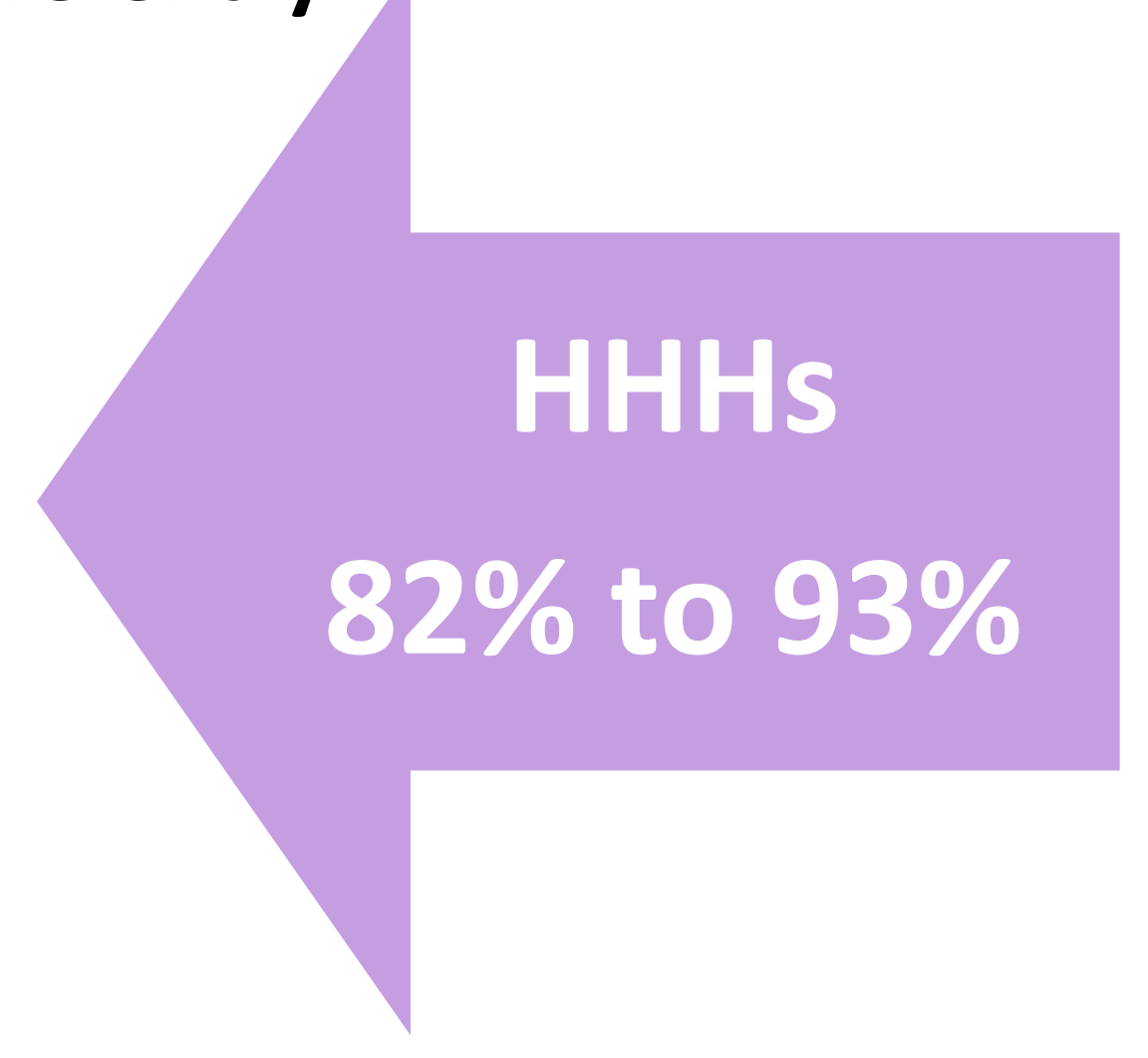

$p<0.001$ 


\section{An increase in policy awareness}

Aware of radio show about girls returning to school

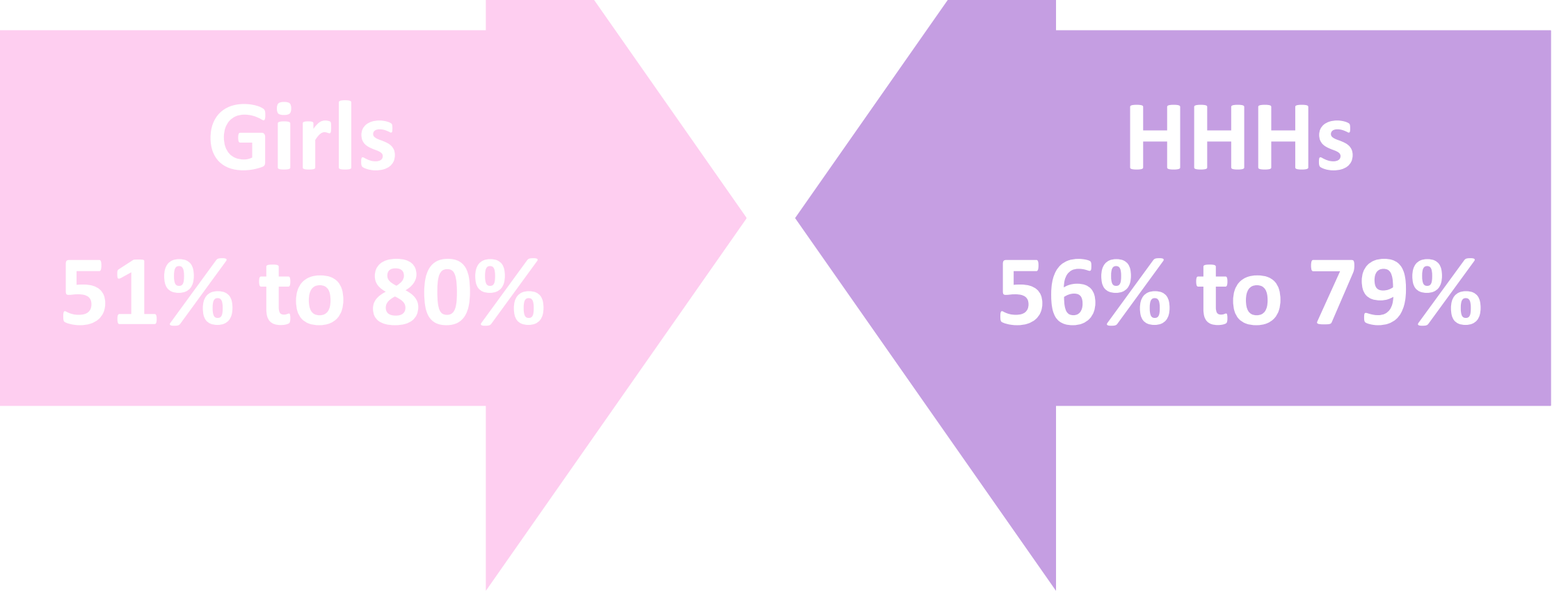

$p<0.001$ 


\section{An increase in policy awareness}

\section{Girls}

\section{HHHs}

Ever heard pregnant girls can remain in

school

$64 \%$ to $72 \%$
Ever heard pregnant girls can remain in school

$p<0.05$

$p<0.001$ 


\section{An increase in policy awareness}

Ever heard parenting girls can return to school 
A wider range of policy information sources

- Parent/guardian

- Baseline: 7\%

- Endline: $14 \% *$

\section{HHHs}

- School/School Head

- Baseline: 19\% Endline: $33 \% * *$

- Comm. member

- Baseline: $\mathbf{4 3 \%}$

- Endline: 50\%* 


\section{A change in parental $(\mathrm{HHH})$ attitudes}

\begin{tabular}{|c|c|}
\hline $51 \%$ to $68 \% * *$ & $\begin{array}{l}\text { Pregnant girls } \\
\text { should be allowed } \\
\text { to stay in school } \\
\text { until delivery }\end{array}$ \\
\hline$\%$ to $33 \% * *$ & $\begin{array}{l}\text { Pregnant girls should } \\
\text { be sent home until } \\
\text { delivery, and then } \\
\text { return to school }\end{array}$ \\
\hline
\end{tabular}




\section{A change in parental $(\mathrm{HHH})$ attitudes}

'Pregnant girls should be allowed back in school after delivery': $\mathbf{9 8 \%}$ to $100 \% *$

'Because everyone has a right to education': $19 \%$ to $33 \% * *$

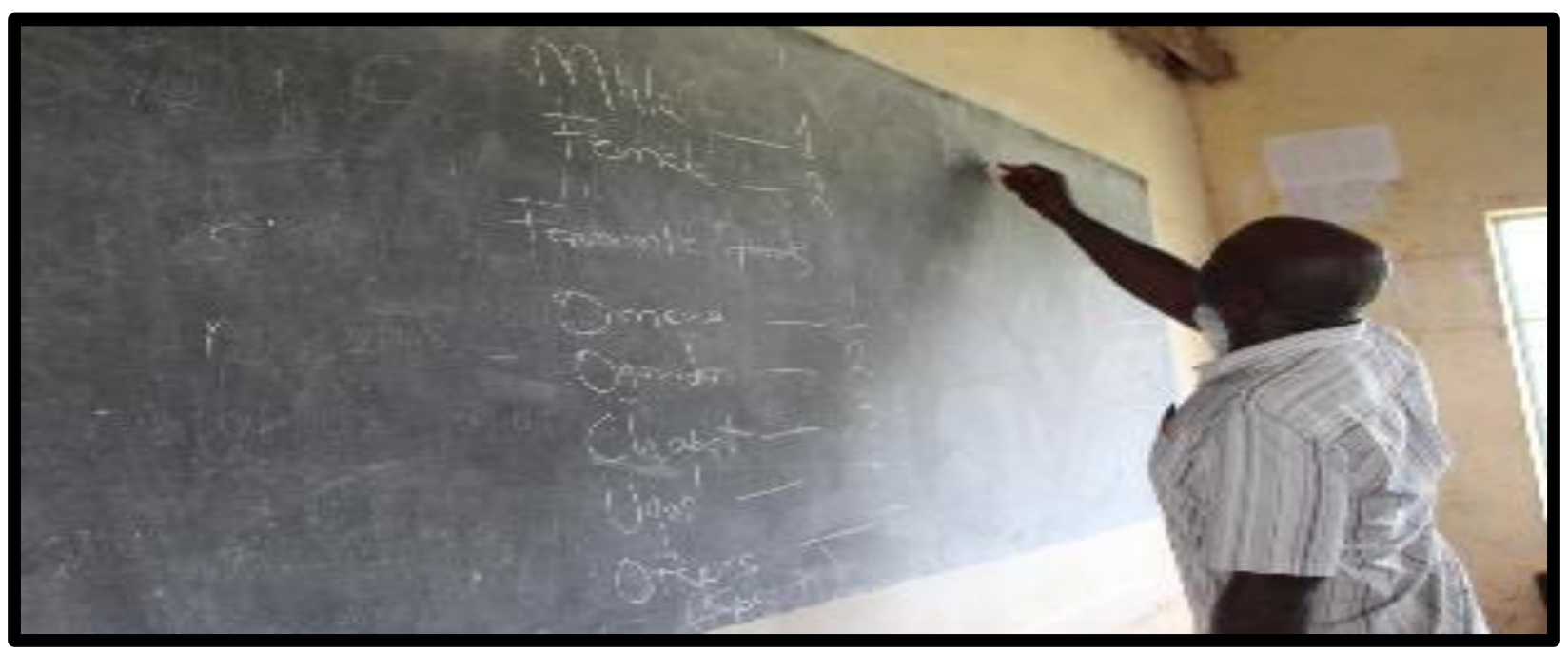




\section{Change in girls' re-entry behavior}

\section{Know of a}

parenting girl

who returned to

school

- HHHs: $88 \%$ to $92 \% *$

- Girls: $80 \%$ to $82 \%$
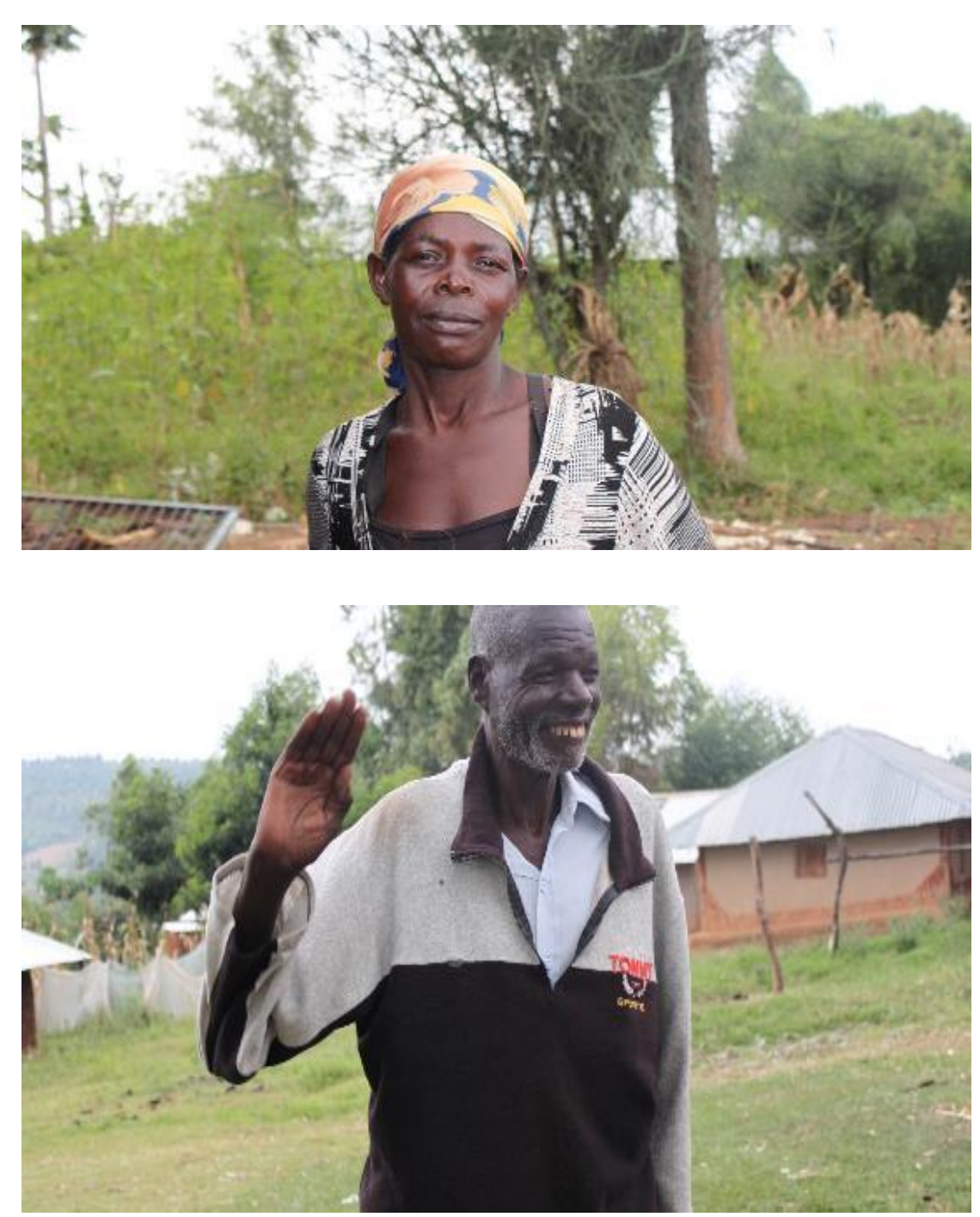


\section{Change in girls' re-entry behavior (Out-of-school girls)}

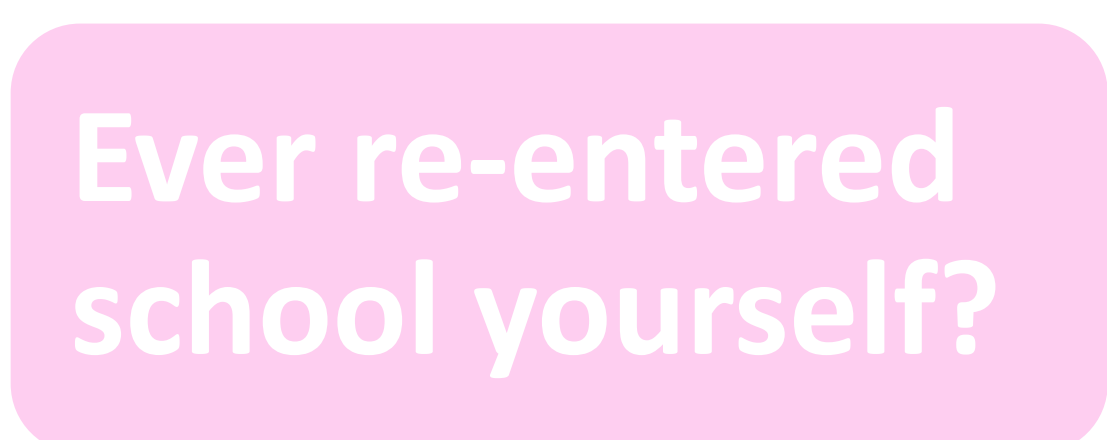

- $10 \%$ to $16 \% *$

\section{Main reasons for leaving school aรain}

- Financial constraints

- Lack of child care 


\section{Pregnancy still a major barrier for girls'}

schooling in Homa Bay despite continuation policies

- Main reason cited by girls for leaving school initially is still pregnancy

- Baseline: $66 \%$

- Endline: 63\%

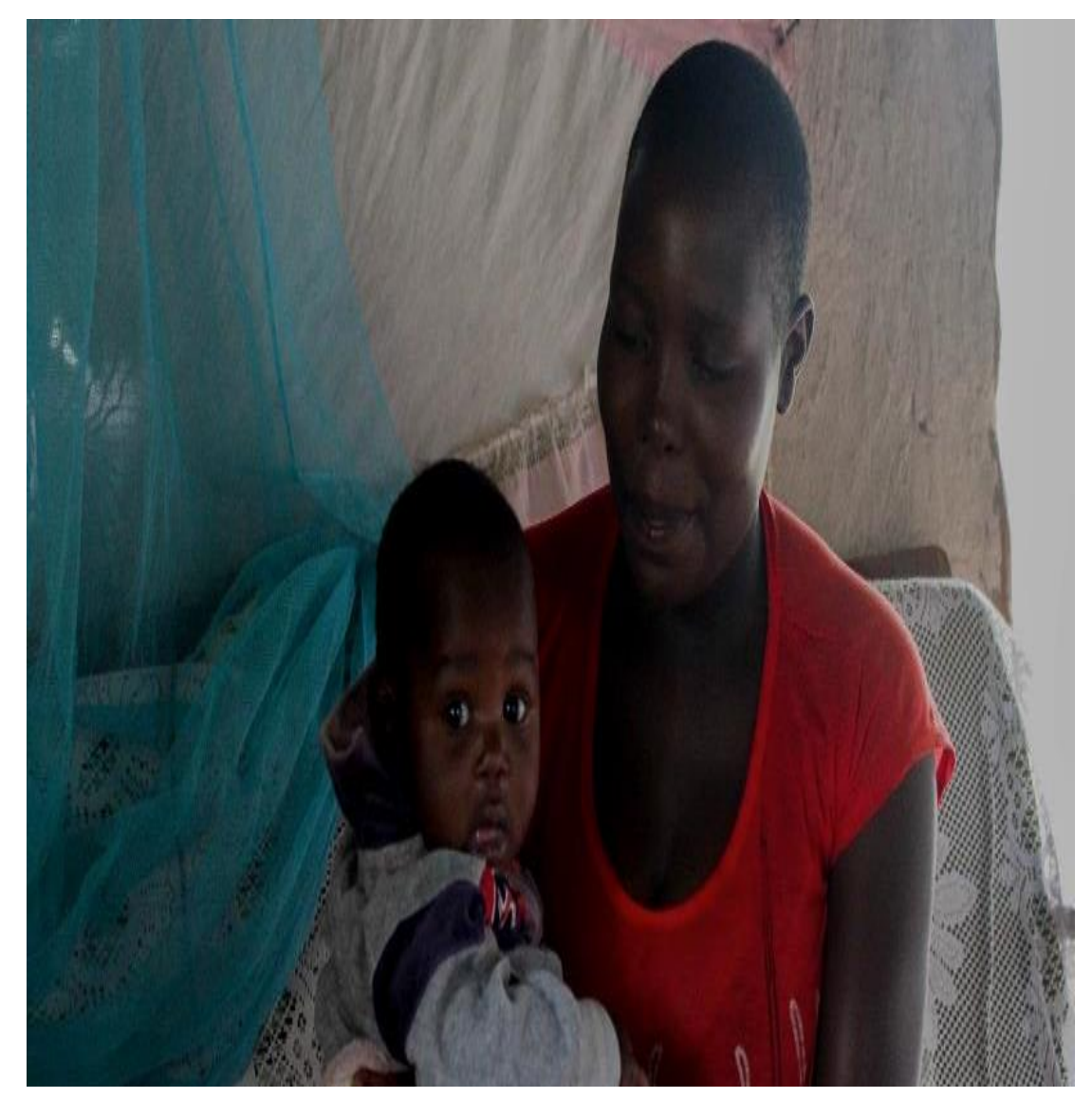




\section{Conclusion}

- Preliminary findings suggest that a combination of policy dialogue, clarification, and advocacy has a positive effect on out-ofschool girls' demand for education, and on wider community KAP.

- However, financial constraints and child care are powerful barriers that must be addressed to ensure school retention after re-entry, or to motivate some families to attempt re-entry at all. 


\section{Limitations}

- Non-use of a cohort study design

- But school statistics from Homa Bay sub-county show re-entry is happening: From Aug 2014 to Sept 2015, 164 girls left primary school, and 140 girls re-entered - many to the same school. 118 girls left secondary school, and 135 girl reentered.

- Lack of a comparison group

- Short intervention period 


\section{References}

Kenya National Bureau of Statistics et al. 2015. Kenya Demographic and Health Survey 2014: Key Indicators. Nairobi, Kenya: Kenya National Bureau of Statistics.

Kenya National Bureau of Statistics. July 2013. Homa Bay County Multiple Indicator Cluster Survey 2011, Final Report. Nairobi, Kenya: Kenya National Bureau of Statistics. 


\section{Acknowledgments}

\section{Our gratitude goes to:}

$\checkmark$ Homa Bay County Department of Education

$\checkmark$ Hon. Naphtally Mattah, Executive CEC, Education, and ICT

$\checkmark$ Hon. Gladys Wanga ('Mama County')

$\checkmark$ Hon. Peter Kaluma

$\checkmark$ Hon. Augustinho Neto

$\checkmark$ Other Members of Parliament

$\checkmark$ Homa Bay County school principals

$\checkmark$ Homa Bay County students

$\checkmark$ Out-of-school girls in Homa Bay County

$\checkmark$ Parents and other HHHs

$\checkmark$ Our data collection team

- Cover slide photo courtesy of gdstone (http://www.flickr.com/people/gdstone/). 


\section{Acknowledgments}

- Thank you, Jane Musia!

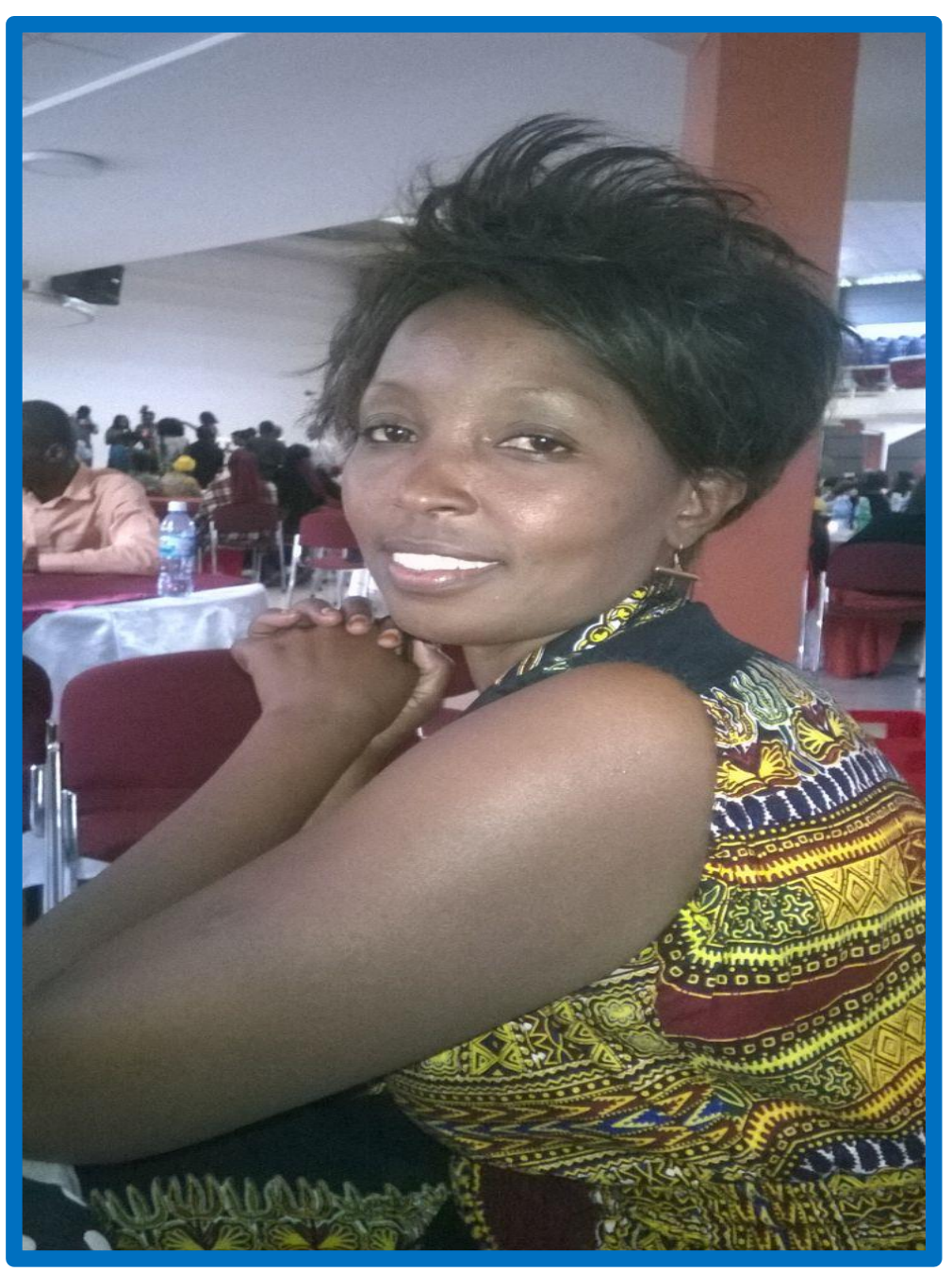




\section{Thank you for your attention}

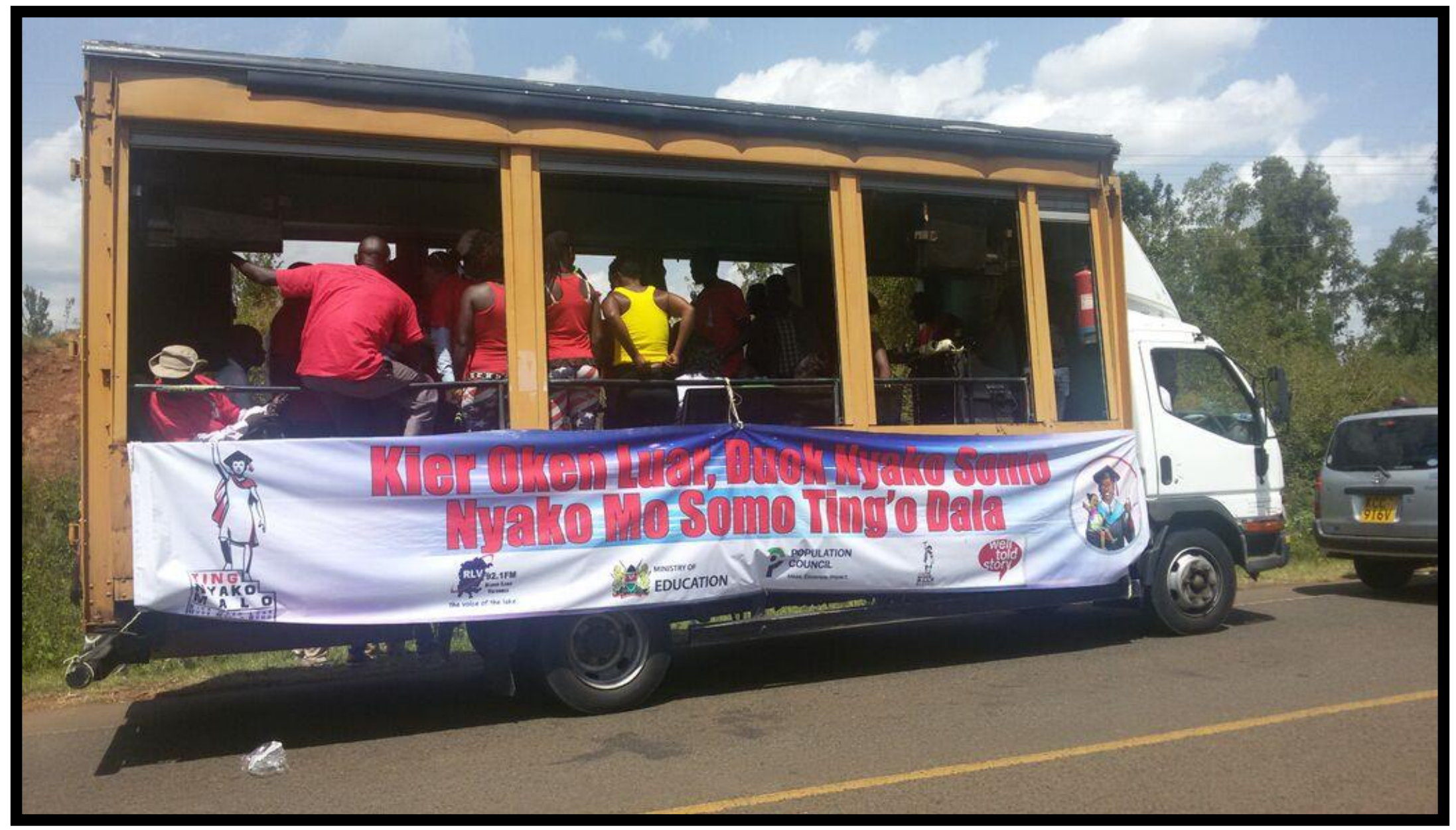




\section{The}

\section{Population Council}

conducts biomedical, social science, and public health research. We deliver solutions that lead to more effective policies, programs, and technologies that improve lives around the world. 